Tropical Journal of Pharmaceutical Research March 2019; 18 (3): 547-554

ISSN: $1596-5996$ (print); 1596-9827 (electronic)

(C) Pharmacotherapy Group, Faculty of Pharmacy, University of Benin, Benin City, 300001 Nigeria.

\title{
Ethylacetate fraction of Anthocleista vogelii Planch demonstrates antiobesity activities in preclinical models
}

\author{
Gabriel O Anyanwu ${ }^{1,2}$, Hafiz Misbah ud Din Qamar ${ }^{2}$, Jamshed Iqbal ${ }^{3}$, Syeda A \\ Ejaz $^{3}$, Eusebius C Onyeneke ${ }^{4 *}$, Shafi U Khan ${ }^{5}$, Khalid Rauf ${ }^{2}$, Nisar-ur-Rahman ${ }^{2}$ \\ ${ }^{1}$ Department of Biochemistry, Bingham University, Karu, Nasarawa State, Nigeria, ${ }^{2}$ Department of Pharmacy, ${ }^{3}$ Centre for \\ Advanced Drug Research, COMSATS University Islamabad, Abbottabad Campus, Abbottabad, KPK, Pakistan, ${ }^{4}$ Department of \\ Biochemistry, University of Benin, Benin City, Nigeria, ${ }^{5}$ School of Pharmacy, Monash University Malaysia, Jalan Lagoon \\ Selatan, 47500 Bandar Sunway, Selangor, Malaysia
}

*For correspondence: Email: eusebius.onyeneke@uniben.edu; Tel: +234-8023327930

Revised accepted: 13 February 2019

\begin{abstract}
Purpose: To assess the anti-obesity effect of liquid chromatography mass spectrometry (LCMS) profiled ethylacetate fraction (EF) of Anthocleista vogelii Planch on pancreatic lipase activity in vitro, and on obesity-related hormones in high-fat diet (HFD)-induced obese rats.

Methods: Chromatographic analysis of EF to identify bioactive compounds was performed using LCMS electrospray ionization mass spectrometry (ESI-MS) positive mode. Thirty Sprague-Dawley rats were divided into 5 groups $(n=6)$. Group 1 was fed normal pellet diet, while groups 2 - 5 were fed high-fat diet (HFD) for 14 weeks. The rats were treated for 4 weeks from week 10 with $125 \mathrm{mg} / \mathrm{kg}$ of EF (group 3), $250 \mathrm{mg} / \mathrm{kg}$ of $E F$ (group 4) or $100 \mathrm{mg} / \mathrm{kg}$ of orlistat (group 5).

Results: Seven alkaloids were identified in EF, namely, 10-hydroxycamtothecin, moschamindole, camptothecin, moschamine, N6-cis-p-coumaroylserotonin, sinomenine and desacetylcolchicine. The EF of A. vogelii exhibited inhibitory activity against pancreatic lipase with half-maximal inhibitory concentration (IC $\left.C_{50}\right)$ of $8.76 \pm 0.110 \mu \mathrm{g} / \mathrm{mL}$. Rats treated with EF (125 and $250 \mathrm{mg} / \mathrm{kg}$ ) of A. vogelii showed significantly $(p<0.05)$ decreased feed intake, body weight, leptin and insulin, when compared to HFD controls. Cortisol, serotonin and noradrenaline were significantly $(p<0.05)$ increased, but changes in thyroid hormones levels in EF-treated rats were not significant $(p>0.05)$ when compared to HFD controls.

Conclusion: The EF of A. vogelii demonstrate anti-obesity activities by inhibiting pancreatic lipase, elevating serotonin and noradrenaline, and increasing leptin sensitivity, leading consequently to decreased body weight of rats. However, the clinical use of EF of A. vogelii as an antiobesity herbal remedy requires further studies on its mechanisms of action.
\end{abstract}

Keywords: Obesity, Anthocleista vogelii, Lipase, High-fat diet, Cortisol, Serotonin, Noradrenaline, Leptin, Insulin

This is an Open Access article that uses a funding model which does not charge readers or their institutions for access and distributed under the terms of the Creative Commons Attribution License (http://creativecommons.org/licenses/by/4.0) and the Budapest Open Access Initiative (http://www.budapestopenaccessinitiative.org/read), which permit unrestricted use, distribution, and reproduction in any medium, provided the original work is properly credited.

Tropical Journal of Pharmaceutical Research is indexed by Science Citation Index (SciSearch), Scopus, International Pharmaceutical Abstract, Chemical Abstracts, Embase, Index Copernicus, EBSCO, African Index Medicus, JournalSeek, Journal Citation Reports/Science Edition, Directory of Open Access Journals (DOAJ), African Journal Online, Bioline International, Open-J-Gate and Pharmacy Abstracts

\section{INTRODUCTION}

Obesity can be defined as an increase in body weight beyond the limits of physical need, resulting from excessive accumulation of fat [1]. It is a chronic condition that is better prevented than cured, because it is difficult to treat. When prevention is unsuccessful, medicinal treatment 
of obesity becomes vital to prevent the development of hypertension, diabetes or heart diseases which are usually associated with obesity [2]. Today, many individuals are sincerely concerned about their body weight due to the increasing sensitization, the health risks or social stigmatization associated with obesity. In the treatment and management of obesity, drugs such as sibutramine, phentermine, exenatide, pramlintide, metreleptin and orlistat (pancreatic lipase inhibitor) have been used over the years, but these drugs have their side effects [3]. While sibutramine has been withdrawn, orlistat remains an over-the-counter drug in many countries, however, orlistat has side effects like flatulence and oily stools [3].

In the search for new antiobesity drugs, researchers are continually investigating lipase inhibitory activity, and regulation of neurotransmitters and endocrine hormones, as possible therapeutic targets. Neurotransmitters like serotonin (5HT), noradrenalin (NA) and dopamine (DA), and hormones like leptin, insulin, triiodothyronine (T3), thyroxine (T4), thyroidstimulating hormone (TSH) and cortisol are some of the modulators that have been the focus of obesity research $[2,3,4]$.

Research into antiobesity agents from plants is ongoing in different parts of the world. Anthocleista vogelii is one plant that has received recent attention. The ethnobotany and pharmacological properties of $A$. vogelii have been well reviewed [5]. This study sought to evaluate the weight, neurotransmitter and endocrine status of diet induced obese SpragueDawley rats treated with ethylacetate fraction (EF) from Anthocleista vogelii root bark, and the lipase inhibitory activity in vitro of the EF.

\section{EXPERIMENTAL}

\section{Plant material}

The fresh parts of $A$. vogelii root bark was obtained from Ovuakali, Umuekwune community, Ngor-okpala, Imo State, Nigeria with authorization of Ngor-okpala Local Government. The plant identification and authentication was done by $\mathrm{Dr}$ JO Ihuma, Biological Sciences Department, Bingham University, Nasarawa State, Nigeria. The plant was allocated the voucher number, GA134-7421.

\section{Preparation of ethyl acetate fraction}

The EF was prepared by macerating $3 \mathrm{~kg}$ of dried powdered root bark of $A$. vogelii in methanol, and the concentrated methanol extract was defatted by extracting with $\mathrm{n}$-hexane. The defatted methanol extract marc was extracted and partitioned with n-butanol saturated with water $(3 \times 500 \mathrm{~mL})$. The aqueous extract was partitioned 3 times with $500 \mathrm{~mL}$ of ethyl acetate using a separating funnel. The ethyl acetate partitions were pooled together and concentrated using a rotary evaporator to obtain EF.

\section{LC-MS/MS analysis}

The chromatographic separations of diluted EF were executed on Agilent 1290 Infinity LC system attached to Agilent 6520 Accurate-Mass $\mathrm{Q}$-TOF mass spectrometer on ESI positive mode. The LC-ESI-MS parameters and experiment were performed as previously described by Anyanwu et al [6]. The MS parameters were as follows: source voltage was $3500 \mathrm{~V}$, the Fragmentor voltage and Skimmer were $125 \mathrm{~V}$ and $65 \mathrm{~V}$ respectively and OCT $1 \mathrm{RF}$ Vpp was $750 \mathrm{~V}$. The drying gas was set at 10 $\mathrm{L} / \mathrm{min}$ and gas temperature at $300{ }^{\circ} \mathrm{C}$. Analyses were carried out on full scan mode, $100-3200$ mass range $(\mathrm{m} / \mathrm{z})$, and processing of acquired data was done with Agilent MassHunter Qualitative Analysis B.05.00.

\section{Pancreatic lipase inhibitory activity}

The method used to determine the inhibitory pancreatic lipase activity for EF was as described by Kim et al [7] with slight modifications. Twenty microlitre of either EF or orlistat at different concentrations $(2.35,4.69,9.38,18.75,37.5,75$, 150 , and $300 \mu \mathrm{g} / \mathrm{mL}$ ) was added to $164 \mu \mathrm{L}$ of assay buffer and $6 \mu \mathrm{L}$ pancreatic lipase solution in each well. After incubation for $10 \mathrm{~min}$ at $37^{\circ} \mathrm{C}$, $10 \mu \mathrm{L}$ of $10 \mathrm{mM} \mathrm{p}$-NPB (p-nitrophenyl butyrate) in assay buffer was added and incubated at $37^{\circ} \mathrm{C}$ for $15 \mathrm{~min}$. Absorbance readings were taken at $405 \mathrm{~nm}$ using a microplate reader. EF inhibition of pancreatic lipase activity $(L)$ was calculated as in $\mathrm{Eq} 1$.

$L(\%)=100-\{(B-b / A-a)\} 100 \ldots \ldots \ldots(1)$

where $B=$ activity with inhibitor, $A=$ activity without inhibitor, $\quad \mathrm{b}=$ negative control with inhibitor, and $a=$ negative control without inhibitor.

\section{Animals}

Thirty male Sprague-Dawley rats (150 - $170 \mathrm{~g})$ were purchased from the National Institute of Health, Islamabad, Pakistan and housed in cages at the Animal House, Department of Pharmacy, COMSATS Institute of Information Technology, Abbottabad, Pakistan. 
Acclimatization of the rats under controlled temperature $\left(23 \pm 2^{\circ} \mathrm{C}\right)$ and $12: 12 \mathrm{~h}$ light/dark cycle with water and food ad libitum took 2 weeks. Experimental procedures followed European Community guidelines [8] for animal handling and ethical approval (no. PHM0024/EC/M-4-5.15) was obtained from Research Ethics Committee of Pharmacy Department, CUI, Abbottabad.

\section{Animal grouping and induction of obesity}

The rats were separated into 5 groups of 6 rats per group. Normal pellet diet (NPD) was given to rats in group 1, while groups 2-5 were fed a high fat diet (HFD) for 14 weeks; water was given ad libitum. The HFD was composed of $60 \%$ fat content as described by Onyeneke and Anyanwu [9].

Obesity was induced in 24 rats by feeding with the HFD for 10 weeks while the other 6 rats were fed on the NPD. Treatment with $125 \mathrm{mg} / \mathrm{kg}$ of EF (Group 3), $250 \mathrm{mg} / \mathrm{kg}$ of EF (Group 4) and 100 $\mathrm{mg} / \mathrm{kg}$ of orlistat (Group 5) began after the 10th week and lasted for 4 weeks, but the HFD obese control (Group 2) and NPD control (Group 1) received only normal saline. Doses were selected based on previous unpublished studies. The fraction or standard drug was dissolved in normal saline and orally administered to the animals using a gavage tube.

\section{Blood samples}

At the close of the treatment period, the rats were fasted for $13 \pm 1 \mathrm{~h}$, then anesthetized with isoflurane before blood samples were collected from the rats via cardiac puncture. The blood samples were collected in tubes void of anticoagulant, and after coagulation, they were placed in a centrifuge then spun at $3500 \mathrm{rpm}$ for $15 \mathrm{~min}$ at $25{ }^{\circ} \mathrm{C}$. The serum was separated into new tubes using micro-pipette and preserved at $20^{\circ} \mathrm{C}$.

\section{Brain tissues}

The brain was removed from the skull of the rats and the hypothalamus excised. The brain tissue was rinsed with $1 \mathrm{X}$ phosphate buffered saline (PBS), homogenized in $0.2 \mathrm{~N}$ perchloric acid $\left(\mathrm{HClO}_{4}\right)$, and centrifuged at $10,000 \mathrm{rpm}$ for $5 \mathrm{~min}$ at $2{ }^{\circ} \mathrm{C}$. The supernatant was collected and refrigerated at $-20^{\circ} \mathrm{C}$.

\section{Food intake, body weight and fat mass}

The food intake was recorded daily using a 2decimal-place balance ( $\mathrm{g} /$ day/cage). The body weight of the rats were recorded weekly in grams (g). After blood sample collection as earlier described, the anesthetized rats were dissected from the abdomen, and the white adipose tissue (WAT) which included the epididymal, visceral and retroperitoneal pads, was harvested from each rat. The WAT was placed on filter paper and weighed in grams.

\section{Evaluation of biochemical parameters}

Total cholesterol was determined by the enzymatic endpoint method as described by Trinder [10]. Triglyceride was determined by GPO-PAP method as described by Tietz [11]. HDL-Cholesterol was determined by CHOD-PAP method as described by Tietz [12]. LDLCholesterol assay was based on manufacturer's protocol (Spectrum Diagnostics, Egypt). VLDLCholesterol was calculated as triglycerides value multiplied by 0.2 , and expressed in $\mathrm{mg} / \mathrm{dL}$.

Serum was used to determine the concentrations of total T3, T4, TSH and cortisol by MicroLISA Enzyme Immunoassay test kits (Amgenix International Inc., USA). Supernatants from brain samples were used to assay for serotonin (5-HT) (EIA Serotonin kit, Immunotech, France), noradrenaline (NA) and dopamine (DA) (NA and DA ELISA kit, Cusabio, China) by the enzyme immunoassay technique according to the manufacturer's manual. All blood glucose measurements were performed on blood isolated from the tail using an Accu-Chek glucometer (Roche, Germany). The levels of serum insulin and leptin were determined based on the sandwich ELISA principle (DRG Leptin and Insulin ELISA kits, USA).

\section{Histopathological studies}

A part of the liver was excised, washed with water and placed in 10\% neutral buffered formalin for histopathology examination. Sections of the liver were prepared and stained with haematoxylin and eosin following fixation. Permanent mounts were examined by light microscopy and the results obtained from treated rats were compared with controls [13].

\section{Statistical analysis}

The results of the experiments were arranged as mean \pm SEM (standard error of mean). Data collected were analyzed on Graphpad Prism 6 using one-way ANOVA, followed by Tukey multiple comparison test to ascertain the significant differences amongst groups. $P<0.05$ was set as statistically significant. 


\section{RESULTS}

\section{Phytochemical composition of EF}

The classes of phytochemicals included in the EF were benzoic acids, amino acids, organic acids and derivatives, lipids, terpenoids, alkaloids, imides, flavonoids (Supplementary information). Alkaloids were more in number than other classes of phytochemicals found in EF of $A$. vogelii, and these include: 10Hydroxycamtothecin (13), moschamindole (15), camptothecin (16), moschamine (17), N6-cis-pcoumaroylserotonin (18), sinomenine $(19,20)$ and desacetylcolchicine (24) (Figure 1, Table 1).

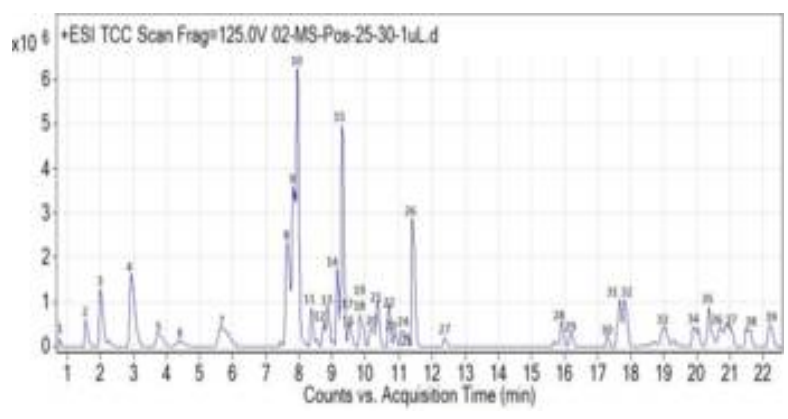

Figure 1: Total compound chromatogram (TCC) of LC-ESI/MS analysis of EF of $A$. vogelii

Table 1: Report of compounds identified in EF of $A$. vogelii

\begin{tabular}{|c|c|c|c|c|c|}
\hline Peak & RT & Mass & Name & Formula & Class \\
\hline 1 & 0.77 & 165.08 & Benzocaine & $\mathrm{C} 9 \mathrm{H} 11 \mathrm{NO} 2$ & Benzoic acid esters \\
\hline 2 & 1.57 & 179.06 & p-Acetaminobenzoic acid & C9 H9 NO3 & Amidobenzoic acid \\
\hline 3 & 2.017 & 163.06 & p-Acetaminobenzaldehyde & $\mathrm{C} 9 \mathrm{H} 9 \mathrm{NO} 2$ & Amidobenzoic acid \\
\hline 4 & 2.951 & 193.07 & Phenylacetylglycine & $\mathrm{C} 10 \mathrm{H} 11 \mathrm{NO} 3$ & n-acyl-alpha amino acids \\
\hline 5 & 3.766 & 164.08 & gamma-Thujaplicin & C10 H12 O2 & Tropolones \\
\hline 6 & 4.403 & 170.09 & Furfural diethyl acetal & C9 H14 O3 & Furans \\
\hline 7 & 5.724 & 177.08 & 2-Propenyl 2-aminobenzoate & $\mathrm{C} 10 \mathrm{H} 11 \mathrm{NO} 2$ & Benzoic acid esters \\
\hline 8 & 7.627 & 207.09 & Phenylpropionylglycine & C11 H13 N O3 & n-acyl-alpha amino acids \\
\hline 9 & 7.815 & 236.12 & Ala Phe & $\mathrm{C} 12 \mathrm{H} 16 \mathrm{~N} 2 \mathrm{O} 3$ & Dipeptide \\
\hline 10 & 7.95 & 366.12 & N-Caffeoyltryptophan & C20 H18 N2 O5 & n-acyl-alpha amino acids \\
\hline 11 & 8.365 & 164.08 & gamma-Thujaplicin & $\mathrm{C} 10 \mathrm{H} 12 \mathrm{O} 2$ & Tropolones \\
\hline 12 & 8.725 & 196.07 & Xanthoxylin & $\mathrm{C} 10 \mathrm{H} 12 \mathrm{O} 4$ & Alkyl-phenylketones \\
\hline 13 & 9.011 & 364.11 & 10-Hydroxycamtothecin & $\mathrm{C} 20 \mathrm{H} 16 \mathrm{~N} 2 \mathrm{O} 5$ & Quinolone alkaloid \\
\hline 14 & 9.294 & 196.07 & Phlorisobutyrophenone & $\mathrm{C} 10 \mathrm{H} 12 \mathrm{O} 4$ & Phenol \\
\hline 15 & 9.348 & 350.13 & Moschamindole & $\mathrm{C} 20 \mathrm{H} 18 \mathrm{~N} 2 \mathrm{O} 4$ & Alkaloid \\
\hline 16 & 9.496 & 348.11 & Camptothecin & C20 H16 N2 O4 & Alkaloid \\
\hline 17 & 9.546 & 352.14 & Moschamine & $\mathrm{C} 20 \mathrm{H} 20 \mathrm{~N} 2 \mathrm{O} 4$ & Alkaloid \\
\hline 18 & 9.621 & 322.13 & N6-cis-p-Coumaroylserotonin & $\mathrm{C} 19 \mathrm{H} 18 \mathrm{~N} 2 \mathrm{O} 3$ & Alkaloid \\
\hline 19 & 9.927 & 329.16 & Sinomenine & $\mathrm{C} 19 \mathrm{H} 23 \mathrm{~N} \mathrm{O} 4$ & $\begin{array}{l}\text { Morphinans/ Opiate } \\
\text { alkaloids }\end{array}$ \\
\hline 20 & 10.217 & 329.16 & Sinomenine & $\mathrm{C} 19 \mathrm{H} 23 \mathrm{~N} \mathrm{O} 4$ & $\begin{array}{l}\text { Morphinans/ Opiate } \\
\text { alkaloids }\end{array}$ \\
\hline 21 & 10.359 & 298.13 & Unknown & C17 H18 N2 O3 & \\
\hline 22 & 10.702 & 209.10 & Tyr-OEt & $\mathrm{C} 11 \mathrm{H} 15 \mathrm{~N} \mathrm{O} 3$ & Amino acids, aromatic \\
\hline 23 & 10.882 & 328.14 & Tyr Phe & $\mathrm{C} 18 \mathrm{H} 20 \mathrm{~N} 2 \mathrm{O} 4$ & Dipeptides \\
\hline 24 & 11.082 & 357.16 & Desacetylcolchicine & $\mathrm{C} 20 \mathrm{H} 23 \mathrm{~N} \mathrm{O} 5$ & Alkaloids \\
\hline 25 & 11.236 & 462.15 & Exoticin & C23 H26 O10 & Flavones and flavonols \\
\hline 26 & 11.421 & 324.15 & p-Hydroxyphenylbutazone & $\mathrm{C} 19 \mathrm{H} 20 \mathrm{~N} 2 \mathrm{O} 3$ & Phenylbutazone \\
\hline 27 & 12.372 & 273.27 & C16 Sphinganine & C16 H35 N O2 & $\begin{array}{l}\text { Ceramide/ 1,2- } \\
\text { aminoalcohols }\end{array}$ \\
\hline 28 & 15.906 & 324.19 & Dinor-PGE2 & C18 H28 O5 & Prostaglandins \\
\hline 29 & 16.187 & 324.19 & Dinor-PGE2 & $\mathrm{C} 18 \mathrm{H} 28 \mathrm{O} 5$ & Prostaglandins \\
\hline 30 & 17.285 & 290.19 & Unknown & $\mathrm{C} 18 \mathrm{H} 26 \mathrm{O} 3$ & \\
\hline 31 & 17.657 & 278.15 & Emmotin A & $\mathrm{C} 16 \mathrm{H} 22 \mathrm{O} 4$ & Sesquiterpenoids \\
\hline 32 & 17.821 & 180.07 & Protionamide & $\mathrm{C} 9 \mathrm{H} 12 \mathrm{~N} 2 \mathrm{~S}$ & Isonicotinic acid \\
\hline 33 & 18.974 & 437.37 & Unknown & C24 H47 N5 O2 & \\
\hline 34 & 19.956 & 281.27 & Oleamide & $\mathrm{C} 18 \mathrm{H} 35 \mathrm{NO}$ & Fatty amides \\
\hline 35 & 20.475 & 378.28 & $\begin{array}{l}\text { 9-deoxy-9-methylene-16,16- } \\
\text { dimethyl -PGE2 }\end{array}$ & $\mathrm{C} 23 \mathrm{H} 38 \mathrm{O} 4$ & Prostaglandins \\
\hline 36 & 20.73 & 342.28 & Eicosanedioic acid & C20 H38 O4 & $\begin{array}{l}\text { Alpha,omega-dicarboxylic } \\
\text { acid }\end{array}$ \\
\hline 37 & 21.027 & 364.30 & 24-Nor-5 $\beta$-cholane-3 $\alpha, 7 \alpha, 23$-triol & $\mathrm{C} 23 \mathrm{H} 40 \mathrm{O} 3$ & Bile acids and derivatives \\
\hline 38 & 21.455 & 390.28 & 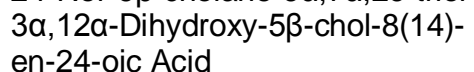 & $\mathrm{C} 24 \mathrm{H} 38 \mathrm{O} 4$ & Bile acid \\
\hline 39 & 22.19 & 586.29 & Unknown & C28 H46 N2 O9 S & \\
\hline
\end{tabular}


Inhibitory activity of EF against pancreatic lipase

The EF of $A$. vogelii displayed inhibitory activity against pancreatic lipase with $\mathrm{IC}_{50}$ value of 8.76 $\pm 0.110 \mu \mathrm{g} / \mathrm{mL}$ (Figure 2), although not as good as Orlistat $\left(\mathrm{IC}_{50}=0.73 \pm 0.015 \mu \mathrm{g} / \mathrm{mL}\right)$.

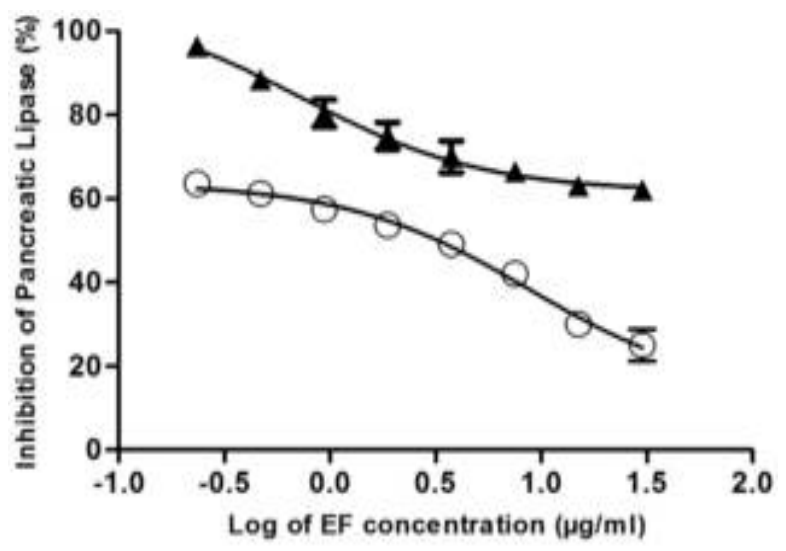

Figure 2: Pancreatic lipase inhibitory activity of EF of A. vogelii and Orlistat. $\boldsymbol{\Delta}=\mathrm{EF}$ of $A$. vogelii; and $\circ=$ Orlistat. The values are expressed as the mean \pm $\operatorname{SEM}(n=3)$

\section{Feed intake, body weight, fat mass and lipid profile}

The group given only HFD had significantly $(p<$ 0.05 ) increased body weight of rats when compared to the normal control (Table 2). Rats treated with $\mathrm{EF}$ (125 and $250 \mathrm{mg} / \mathrm{kg}$ ) of $A$. vogelii displayed significant $(p<0.05)$ decrease in the feed intake and body weight compared to both the normal control and HFD control.

The WAT of the HFD control was significantly ( $p$ $<0.05$ ) higher when compared to the normal control (Table 2). However, EF (125 and 250 $\mathrm{mg} / \mathrm{kg})$ of $A$. vogelii significantly $(\mathrm{p}<0.05)$ decreased WAT when compared to the HFD and normal control. The HFD control group revealed significant $(p<0.05)$ increases in TG, TC, LDL-C and VLDL-C, but a significant $(p<0.05)$ decrease in HDL-C when compared to the normal control (Table 2). The EF (125 and 250 $\mathrm{mg} / \mathrm{kg})$ of $A$. vogelii significantly $(p<0.05)$ decreased TG, TC, LDL-C and VLDL-C but increased significantly $(p<0.05)$ the HDL-C compared to the HFD control. Also, in comparison with the normal control, EF (125 and $250 \mathrm{mg} / \mathrm{kg}$ ) of $A$. vogelii reduced significantly $(p<$ $0.05)$ the TG, TC and VLDL-C only.

\section{Glucose, neurotransmitters and endocrine status of obese rats}

The HFD control group showed a significant $(p<$ $0.05)$ increase in TSH, a decrease $(p<0.05)$ in T4 and no significant $(p>0.05)$ changes in T3 and cortisol levels when compared to the normal control (Table 3). The group treated with EF revealed a significant $(p<0.05)$ decrease in T4, a significant $(p<0.05)$ elevation in cortisol and non-significant $(p<0.05)$ changes in T3 and TSH levels when compared to the HFD control.

The rats in the HFD control group had significantly $(p<0.05)$ reduced $5 \mathrm{HT}$ and NA levels but significantly $(p<0.05)$ elevated DA compared to the normal control (Table 3 ). The 125 and $250 \mathrm{mg} / \mathrm{kg}$ EF revealed significant $(p<$ 0.05 ) increases in $5 \mathrm{HT}$ and NA, but significant ( $p$ $<0.05$ ) decrease in DA compared to the HFD control. There were significant increases in leptin, insulin and glucose levels of the HFD fed rats when compared to the normal control (Table 3). The animals treated with 125 and $250 \mathrm{mg} / \mathrm{kg}$ EF showed significant $(p<0.05)$ decreases in leptin, insulin and glucose levels when compared to HFD control $(p<0.05)$.

Table 2: Effect of EF on food intake, body weight, WAT and lipid profile in obese rats

\begin{tabular}{|c|c|c|c|c|c|}
\hline \multirow{3}{*}{ Parameter } & NPD control & HFD control & Av EF & Av EF & Orlistat \\
\hline & & & (125 mg/kg) & $(250 \mathrm{mg} / \mathrm{kg})$ & $(100 \mathrm{mg} / \mathrm{kg})$ \\
\hline & Group 1 & Group 2 & Group 3 & Group 4 & Group 5 \\
\hline Food intake (g) & $30.65 \pm 0.90^{a}$ & $29.67 \pm 1.86^{\mathrm{a}}$ & $17.46 \pm 2.41^{\mathrm{DC}}$ & $15.79 \pm 1.54^{\mathrm{C}}$ & $29.66 \pm 0.67^{a}$ \\
\hline Body weight (g) & $272.67 \pm 7.13^{\mathrm{bc}}$ & $312.00 \pm 12.49^{a}$ & $263.00 \pm 9.71^{c}$ & $253.00 \pm 10.21^{c}$ & $275.33 \pm 4.67^{\mathrm{bc}}$ \\
\hline WAT $(g)$ & $12.80 \pm 0.27^{b}$ & $17.96 \pm 0.84^{a}$ & $4.96 \pm 1.77^{\mathrm{C}}$ & $4.32 \pm 1.52^{\mathrm{C}}$ & $12.74 \pm 0.86^{\mathrm{b}}$ \\
\hline $\mathrm{TG}(\mathrm{mg} / \mathrm{dL})$ & $117.38 \pm 4.88^{b}$ & $133.05 \pm 2.94^{\mathrm{a}}$ & $92.89 \pm 2.27^{\mathrm{cd}}$ & $89.89 \pm 1.85^{d}$ & $92.98 \pm 1.07^{\mathrm{cd}}$ \\
\hline $\mathrm{TC}(\mathrm{mg} / \mathrm{dL})$ & $100.49 \pm 1.17^{a}$ & $130.75 \pm 2.25^{\mathrm{a}}$ & $108.16 \pm 4.30^{\mathrm{bc}}$ & $105.16 \pm 4.40^{\mathrm{cd}}$ & $115.05 \pm 1.29^{\mathrm{bC}}$ \\
\hline LDL-C (mg/dL) & $42.20 \pm 2.94^{c}$ & $104.93 \pm 2.24^{\mathrm{a}}$ & $84.54 \pm 4.08^{\mathrm{b}}$ & $81.54 \pm 3.96^{\mathrm{D}}$ & $79.40 \pm 2.81^{\mathrm{D}}$ \\
\hline HDL-C (mg/dL) & $38.94 \pm 0.97^{c}$ & $37.02 \pm 0.88^{c}$ & $58.71 \pm 3.13^{\mathrm{ab}}$ & $61.61 \pm 3.10^{\mathrm{a}}$ & $42.29 \pm 1.19^{c}$ \\
\hline VLDL-C (mg/dL) & $23.48 \pm 0.98^{b}$ & $26.61 \pm 0.59^{a}$ & $18.58 \pm 0.45^{c}$ & $17.98 \pm 0.37^{c}$ & $18.60 \pm 0.21^{c}$ \\
\hline
\end{tabular}

Values are presented as mean \pm SEM. Means in the same rows not sharing common letter(s) are significantly different $(p<0.05)$. 
Table 3: Effect of EF on neurotransmitters, hormones and glucose concentrations in obese rats

\begin{tabular}{|c|c|c|c|c|c|}
\hline & NPD control & HFD control & Av EF & Av EF & Orlistat \\
\hline \multirow[t]{2}{*}{ Parameter } & & & $(125 \mathrm{mg} / \mathrm{kg})$ & $(250$ mg/kg) & $(100 \mathrm{mg} / \mathrm{kg})$ \\
\hline & Group 1 & Group 2 & Group 3 & Group 4 & Group 5 \\
\hline T3 ( $\mu \mathrm{g} / \mathrm{dL})$ & $1.56 \pm 0.25^{D}$ & $1.49 \pm 0.06^{\mathrm{D}}$ & $1.49 \pm 0.05^{b}$ & $1.40 \pm 0.08^{\mathrm{D}}$ & $0.63 \pm 0.14^{\mathrm{C}}$ \\
\hline TSH $(\mu \mathrm{g} / \mathrm{dL})$ & $0.12 \pm 0.00^{a}$ & $0.20 \pm 0.00^{a}$ & $0.20 \pm 0.01^{a}$ & $0.17 \pm 0.02^{\mathrm{bc}}$ & $0.19 \pm 0.01^{\mathrm{ab}}$ \\
\hline Cortisol ( $\mu \mathrm{g} / \mathrm{dL})$ & $0.91 \pm 0.81^{c}$ & $1.15 \pm 1.10^{C}$ & $8.42 \pm 0.88^{\mathrm{a}}$ & $7.42 \pm 0.90^{\mathrm{a}}$ & $5.66 \pm 0.61^{\mathrm{ab}}$ \\
\hline $5 \mathrm{HT}(\mathrm{ng} / \mathrm{g})$ & $11.51 \pm 0.53^{b}$ & $8.75 \pm 1.37^{\mathrm{C}}$ & $15.24 \pm 0.75^{\mathrm{ab}}$ & $16.58 \pm 0.58^{a}$ & $10.98 \pm 0.85^{b}$ \\
\hline $\mathrm{DA}(\mathrm{ng} / \mathrm{mL})$ & $1.35 \pm 0.03^{\mathrm{b}}$ & $7.63 \pm 0.79^{a}$ & $0.43 \pm 0.09^{c}$ & $0.45 \pm 0.07^{\mathrm{C}}$ & $0.33 \pm 0.02^{c}$ \\
\hline $\mathrm{NA}(\mathrm{pg} / \mathrm{mL})$ & $19.34 \pm 2.78^{b}$ & $15.42 \pm 1.80^{\mathrm{c}}$ & $68.82 \pm 3.86^{\mathrm{a}}$ & $70.48 \pm 2.36^{a}$ & $79.47 \pm 9.55^{\mathrm{a}}$ \\
\hline Leptin (ng/mL) & $0.09 \pm 0.01^{\mathrm{c}}$ & $0.60 \pm 0.07^{\mathrm{a}}$ & $0.43 \pm 0.04^{\mathrm{b}}$ & $0.33 \pm 0.03^{\mathrm{b}}$ & $0.64 \pm 0.04^{\mathrm{a}}$ \\
\hline Insulin ( $\mu \mathrm{lU} / \mathrm{mL})$ & $1.75 \pm 0.18^{c}$ & $3.79 \pm 0.43^{\mathrm{a}}$ & $1.93 \pm 0.11^{\mathrm{bc}}$ & $1.73 \pm 0.04^{\mathrm{c}}$ & $2.37 \pm 0.12^{\mathrm{b}}$ \\
\hline Glucose (mmol/L) & $11.73 \pm 0.41^{\mathrm{D}}$ & $16.50 \pm 0.50^{\mathrm{a}}$ & $12.07 \pm 0.11^{\mathrm{b}}$ & $11.52 \pm 0.43^{\mathrm{b}}$ & $11.51 \pm 0.49^{\mathrm{b}}$ \\
\hline
\end{tabular}

Values are presented as mean \pm SEM. Different letter(s) on the mean values in the same row indicates significant difference $(p<0.05)$

\section{Histopathological features of liver}

Photomicrographs of the liver revealed that the HFD control groups had large fat deposits at focal areas and moderate inflammation (Figure 3). Rats treated with $125 \mathrm{mg} / \mathrm{kg}$ EF showed slight distortion in the liver structure with numerous microvascular fat deposits. However, rats treated with $250 \mathrm{mg} / \mathrm{kg}$ EF showed normal liver morphology without structural distortions or fat deposits.

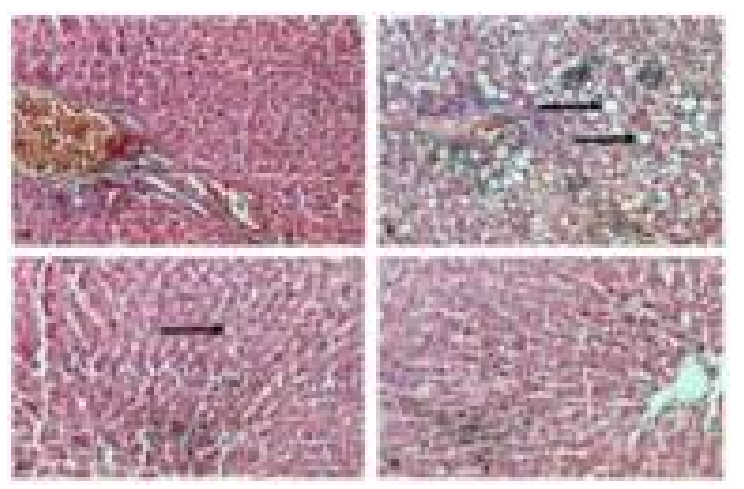

Figure 3: Photomicrograph of the liver of rats treated with EF of $A$. vogelii. Note: Light microscope images of liver tissues stained with hematoxylin and eosin were of X20 magnification. A- Normal control; B- HFD control and $(\rightarrow)$ indicates presence macrovascular fat deposit; C- $125 \mathrm{mg} / \mathrm{kg}$ EF and $(\rightarrow)$ indicates microvascular fat deposit; and D- $250 \mathrm{mg} / \mathrm{kg}$ EF shows reversal of fat deposit

\section{DISCUSSION}

The compounds in EF listed on Table 1 have not been reported for possible anti-obesity activities except benzocaine, phenylacetylglycine and moschamine. Benzocaine in combination with phenylpropanolamine has been shown to have weight loss effects, although benzocaine as a single drug was ineffective based on a single randomized clinical trial [14]. Moschamine has been reported to possess serotonergic inhibitory activities [15], while phenylacetylglycine has been shown to be involved in obesity however, its effect is not yet clear [16].

Pancreatic lipase, secreted from the pancreas facilitates the absorption of triglycerides in the small intestine from dietary fat, thus, inhibitors of pancreatic lipases function as antiobesity agents. Ethylacetate fraction from $A$. vogelii inhibited the activity of PLE suggesting its antiobesity potential, and this was evidenced in the reduced body weight and fat mass of animals that received EF of $A$. vogelii. Reduced absorption of ingested dietary fat leads to an overall reduced caloric absorption, thereby leading to weight loss [17].

According to de Graaf et al [18] appetite could be determined by measuring actual food intake (i.e., the amount of food consumed within a specific context). The EF of $A$. vogelii reduced the food intake of the animals, and by implication their appetite was reduced. The decrease in body weight and WAT of the animals could be partly attributed to the significant decrease in their food intake. Since increased fat mass can be directly correlated with obesity [19], the reduction in WAT observed in the treated rats is an indication of the antiobesity potential of EF. The findings that EF reduced the levels of serum TG, TC, LDL-C and VLDL-C is similar to an earlier study for ethanol extracts of $A$. vogelii root bark at a higher concentration of $500 \mathrm{mg} / \mathrm{kg}$ [20],

Research has shown that TSH, T3, and T4 are elevated in obese individuals when compared to those of normal weight [21]. As a result, weight reduction should result in a decline in T3, T4 concentrations, but not in TSH concentrations [21]. However, the EF of $A$. vogelii caused decrease in T4, with no changes in T3 or TSH levels. This indicated that EF had no discernable 
impact on thyroid hormones in obese rats. The $\mathrm{EF}$ increased the levels of cortisol, which might indicate an adjustment to weight reduction in the animals as higher cortisol levels have been linked to weight loss [22].

The elevated levels of 5-HT and NA in the treated animals indicated that EF inhibited 5-HT and NA reuptake thereby increasing the levels of $5-\mathrm{HT}$ and NA in the hypothalamus and consequently suppressing food consumption and reducing body weight. Moschamine, which was identified in EF, has been reported to have serotoninergic inhibitory activity [15]. The EF fractions of $A$. vogelii decreased dopamine levels, which indicate that the fractions might cause increased sensitivity of dopamine in the animals, as dopamine is associated with meal size and satiety [23]. Obesity is characterized by increase in serum glucose, insulin and leptin values [24]. These features were observed in the animals fed with HFD without treatment. The EF of $A$. vogelii effectively decreased levels of leptin, insulin and glucose, thereby reversing the obesity state of the animals. Nonalcoholic fatty liver disease (NAFLD), a medical condition of excess fat deposit in the liver is a common feature of obesity [25]. The $250 \mathrm{mg} / \mathrm{kg} \mathrm{EF}$ of $A$. vogelii induced a complete reversal of the fatty liver condition of the animals.

\section{CONCLUSION}

Overall, the EF of $A$. vogelii exerts significant weight loss effects on rats due to the inhibition of pancreatic lipase and/or increasing levels of serotonin (which suppresses appetite) and noradrenaline (which increases calorie dissipation). The presence of moschamine probably contributes to the plant's serotoninergic inhibitory activity thereby decreasing food intake. Clinical studies are required to determine if EF may also cause reduction in the body weight of humans.

\section{Supporting information}

The total ion chromatogram (TIC) scan, total compound chromatogram (TCC) and tabulated data for all compounds in EF of $A$. vogelii obtained from LCMS/MS positive mode are available as supporting information.

\section{DECLARATIONS}

\section{Acknowledgement}

Third World Academy of Sciences (TWAS) and COMSATS Institute of Information Technology (CIIT), Pakistan (now COMSATS University
Islamabad, Pakistan) supported the first author (Gabriel O Anyanwu) under the 2014 CIIT-TWAS Sandwich Postgraduate Fellowship award (FR no. 3240280470).

\section{Conflict of interest}

The authors declare that no conflict of interest is associated with this work.

\section{Contribution of Authors}

We declare that this work was done by the authors named in this article and all liabilities pertaining to claims relating to the content of this article will be borne by the authors". This study was conceived by Dr. Gabriel and Prof. Onyeneke, the design and supervision was done with contributions from Prof. Nisar-ur-Rahman and Dr. Khalid. The experimental work was done by Dr. Gabriel and Hafiz Misbah, while the LCMS/MS analysis was by Dr. Gabriel and Mr. Khan. Biochemical analysis was done with the support of Prof. Iqbal (Director of CADR) and Abida Ejaz. Dr. Gabriel analyzed the data and wrote the manuscript, however all authors read, edited and approved the manuscript for publication.

\section{REFERENCES}

1. Sikaris KA. The clinical biochemistry of obesity. Clin Biochem Rev 2004; 25: 165- 181.

2. Bray GA, Tartaglia LA. Medicinal strategies in the treatment of obesity. Nature 2000; 404: 672-677.

3. Adan RHA. Mechanisms underlying current and future anti-obesity drugs. Trends Neurosci 2013; 36(2): 133140.

4. Sumithran $P$, Prendergast LA, Delbridge E, Purcell K, Shulkes A, Kriketos A, Proietto J. Long-term persistence of hormonal adaptations to weight loss. N Engl J Med 2011; 365(17): 1597-1604.

5. Anyanwu GO, Ur-Rehman N, Onyeneke EC, Rauf $K$. Medicinal plants of the genus Anthocleista- a review of their ethnobotany, phytochemistry and pharmacology. $J$ Ethnopharmacol 2015; 175: 648-667.

6. Anyanwu GO, Iqbal J, Khan SU, Zaib S, Rauf K, Onyeneke CE, Ojo OO, Nisar-ur-Rahman. Antidiabetic activities of chloroform fraction of Anthocleista vogelii Planch root bark in rats with diet- and alloxan-induced obesity-diabetes. J Ethnopharmacol 2018; 229, 293302.

7. Kim J, Jang DS, Kim H, Kim JS. Anti-lipase and lipolytic activities of ursolic acid isolated from the roots of Actinidia arguta. Arch Pharm Res 2009; 32(7): 983-987.

8. Council Directive 86/609/EEC of 24 November 1986 on the approximation of laws, regulations and administrative provisions of the Member States

Trop J Pharm Res, March 2019; 18(3):553 
regarding the protection of animals used for experimental and other scientific purposes. Official Journal of the European Communities L 358/1, 1-28. Available https://publications. europa.eu/en/publication-detail//publication/cc3a8ccb-5a30-4b6e-8da8b13348caeb0c/language-en

9. Onyeneke EC, Anyanwu GO. Effect of Alstonia boonei De Wild on high fat diet induced obesity in male wistar rats. Eur J Sci Res 2013; 112(3): 292-299.

10. Trinder P. Enzymatic colorimetric method of cholesterol determination. Ann Clin Biochem 1969; 6: 24.

11. Tietz NW. Clinical guide to laboratory tests. 2nd ed. Philadelphia: W.B. Saunders; 1990.

12. Tietz NW. Fundamentals of clinical chemistry. 2nd ed. Philadelphia: W.B. Saunders; Philadelphia, 1976.

13. Dahiru D, Obidoa O. Evaluation of the antioxidant effects of Zizyphus mauritiana lam. leaf extracts against chronic ethanol induced hepatotoxicity in rat liver. Afr $J$ Tradit Complement Altern Med 2008; 5(1): 39-45.

14. Haddock CK, Poston WSC, Dill PL, Foreyt JP, Ericsson M. Pharmacotherapy for obesity: a quantitative analysis of four decades of published randomized clinical trials. Int J Obes (Lond) 2002; 26: 262 - 273.

15. Park JB. Synthesis, biological activities and bioavailability of moschamine, a safflomide-type phenylpropenoic acid amide found in Centaurea cyanus. Nat Prod Res 2012; 26(16): 1465-1472.

16. Sahib NG, Saari N, Ismail A, Khatib A, Mahomoodally A, Abdul Hamid A. Plants' metabolites as potential antiobesity agents. Sci World J 2012; Article ID 436039: 8.
17. Tsujita T, Takaichi H, Takaku T, Aoyama S, Hiraki J. Antiobesity action of E-polylysine, a potent inhibitor of pancreatic lipase. J Lipid Res 2006; 47(8); 1852-1858.

18. De Graaf C, Blom WA, Smeets PA, Stafleu A, Hendriks HFJ. Biomarkers of satiation and satiety. Am J Clin Nutr 2004; 79: 946-961.

19. Haslam DW, James WP. Obesity. Lancet 2005; 366(9492): 1197-209.

20. Anyanwu GO, Onyeneke EC, Usunobun U, Adegbegi AJ. Impact of Anthocleista vogelii root bark ethanolic extract on weight reduction in high carbohydrate diet induced obesity in male wistar rats. Afr J Biochem Res 2013; 7(11): 225-232.

21. Reinehr T, Andler W. Thyroid hormones before and after weight loss in obesity. Arch Dis Child 2002; 87(4): 3203.

22. Shapses SA, Riedt CS. Bone, body weight, and weight reduction: what are the concerns? J Nutr 2006; 136(6): 1453-6.

23. Meguid MM, Fetissov SO, Varma M, Sato T, Zhang $L$, Laviano A, Rossi-Fanelli F. Hypothalamic dopamine and serotonin in the regulation of food intake. Nutrition 2000; 16(10): 843-857.

24. Ahmed HA, Aref MI. Anthropometric measurements and appetite related hormones in obesity patients. Nat Sci 2010; 8(7): 12-19.

25. Marchesini G, Brizi M, Bianchi G, Tomassetti $S$, Bugianesi E, Lenzi M, McCullough AJ, Natale S, Forlani $G$, Melchionda N. Nonalcoholic fatty liver disease: $A$ feature of the metabolic syndrome. Diabetes 2001; 50: 1844-1850. 